\title{
FISCAL EQUALIZATION SYSTEMS FOR EUROPEAN STATES - POSSIBILITIES AND RESTRICTIONS FOR THE ARrangements in Germany AND Poland
}

\author{
ISABELLE JAENCHEN ${ }^{*}$
}

\section{INTRODUCTION AND RELEVANCE OF THE TOPIC}

After the extreme decrease of public revenues during the financial crisis 2008-2011, tax revenues steadily increased again. Nevertheless, the fiscal balances of the majority of European countries are still negative, i.e. the amount of public revenues is smaller than the amount of public spending. This paper shows that this net borrowing is independent of the form of government and aims to offer a solution for the avoidance of future financing deficits.

Considering the financial situation of the 28 member states of the European Union, a depiction of their financial balances shows fig. 1.

Considering the sum of public revenues and public spending of all countries in the EU, at no time in the time span of 2006-2014 were the public revenues sufficient to cover public spending. In the chart above, the dotted lines present public revenues. It is irrelevant whether one regards all members of the EU or only the members of the EURO-Zone, there is a financial deficit in all cases. The biggest deficit occurs during the years of the crisis 2008-2011. 2014 and 2015 see a decrease of the deficits in most countries of the EU, due to increased tax revenues.

Financial deficits occur independently of the structure of the states. Distinguishing between different state structures, two groups can be formed. The first group contains the 25 states with a (mostly) centralised state structure. Those are organized as unitary states, some centralised, some decentralised ${ }^{1}$. The second group is formed by only three federally organized states: Austria, Belgium and Germany. With regard to the assignment of duties and finances within the states, in an economic sense, those are not federal countries, though. In those countries, as in the unitary states, the financial allocation is mostly task-related, i.e. according to a juridical approach.

DOI: $10.1515 /$ wrlae-2015-0053

* Professor for Public Finance and Economics, PhD in Economics, Department of General Administration, Meissen University of Applied Administrative Sciences, Centre for Continuing Education; isabelle.jaenchen@hsf.sachsen.de

${ }^{1}$ Information about the European member countries cf. European Union, 'European Union' (2016) <https://europa.eu/european-union/about-eu/countries_de> accessed 15 October 2016. 
Fig. 1 Development of total expenditure and total revenue, 2006-14 (1 000 million $€$ )

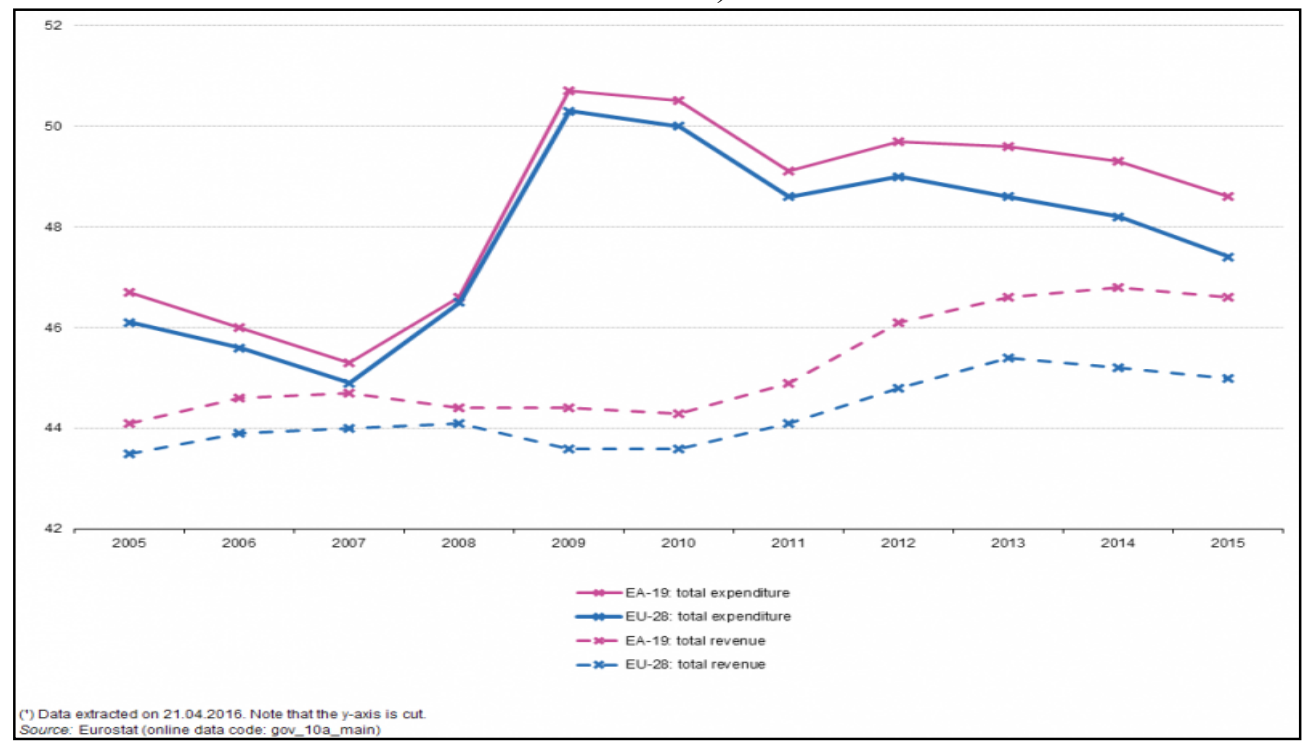

Source: data based on Eurostat 'Government revenue, expenditure and main aggregates ${ }^{6}$

$<$ http://appsso.eurostat.ec.europa.eu/nui/show.do?dataset=gov_10a_main\&1 ang=en $>$ accessed 15 October 2016.

Comparing the development of public revenues and public spending in the U.S. as a federal country with a more economically characterised fiscal equalisation system, it is obvious that such an approach does not necessarily lead to balanced financial situations.

Fig. 2 Public revenues and expenditures in USA (USD in millions)

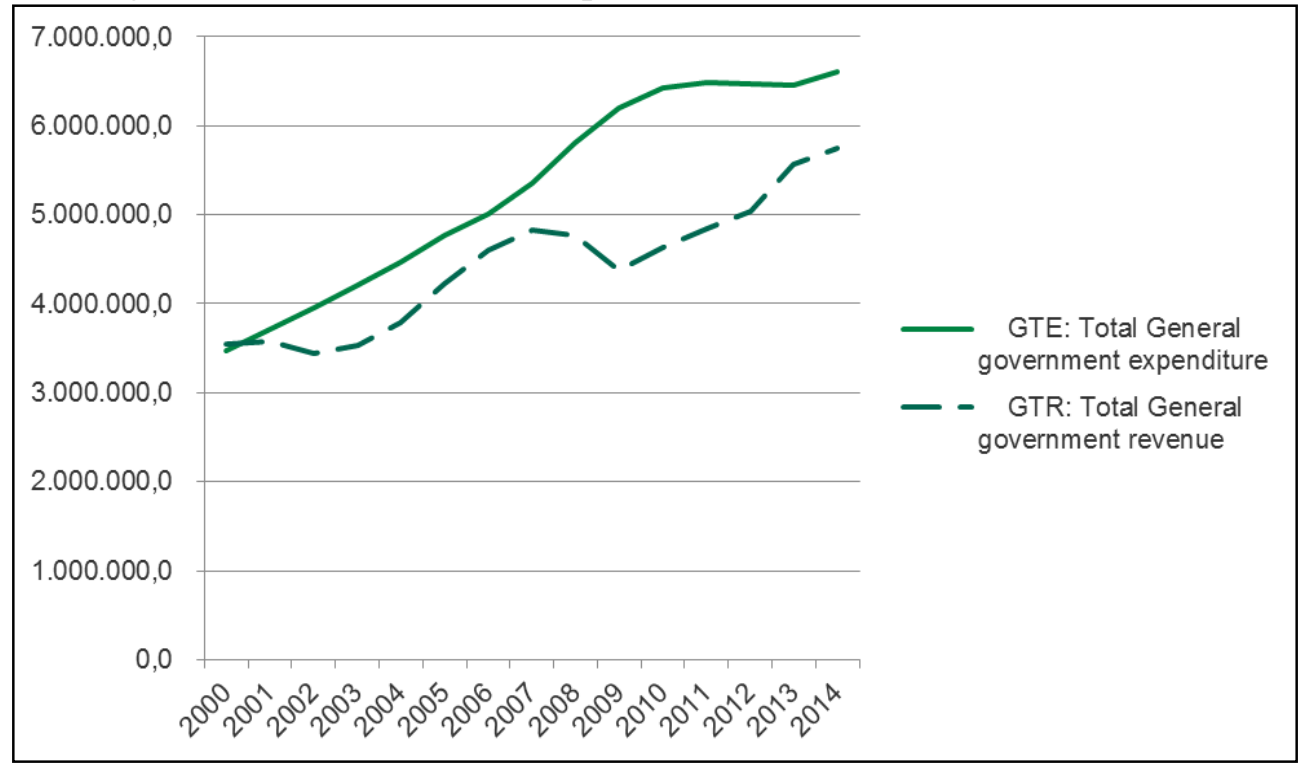

Source: data based on OECD '12th Government deficit/ surplus, revenue, expenditure and main aggregates ${ }^{\prime}<$ www.stats.oecd.org $>$ accessed 15 October 2016. 
The relevant literature distinguishes between a mostly public economics-oriented consideration of the income-aspects and a mostly administrative science-based view of the public spending with regards to controlling and regulation. The existing literature for both topics is wide, so there will be some authors referred to exemplarily. For public economics Blankart $^{2}$ or Brümmerhoff and Büttner ${ }^{3}$ will be cited; for the basics of public economics and especially for this analysis the Jahresgutachten 2014/15 from The German Council of Economic Experts ${ }^{4}$ will be referred to. The research of public spending is associated with public management and administration will reference the publications from Budäus and Hilger ${ }^{5}$, Glöckner ${ }^{6}$ as well as the Bertelsmannstiftung with $\mathrm{KGSt}^{7}$.

The income side discusses the generation of income in general, as well as its allocation to the different levels of the state. The spending side concentrates on the efficient management of tasks and the resulting consequences for public spending. So far, there is no integral approach that combines both aspects. The following text gives a first descriptive introduction by relating the key aspects.

\section{FisCAL EQUALISATION SYSTEMS}

The majority of the necessary public income stems from taxes, i.e. compulsory levies that do not lead to a direct service in return. Therefore, spending for the provision of public services is not linked with tax revenues. The principle of fiscal equivalence ${ }^{8}$, i.e. that the financial contribution covers the costs for the public service, does not apply in this case. In addition, there is the possibility to impose fees for specific purposes, especially at a community level, e.g. for the provision of childcare or infrastructure.

For the organisation of the allocation of finances within the states, i.e. for the constitution of public finance law, there are two approaches: on the one hand, there are juridical regulations for the allocation of public tasks, the resulting spending and the necessary revenues. On the other hand, there are, especially for federal states, suggestions for an economic approach that strongly considers incentives and efficiency in the allocation of public goods and services.

\footnotetext{
${ }^{2}$ Charles Beat Blankart, Öffentliche Finanzen in der Demokratie (8th edn, Vahlen 2011).

3 Dieter Brümmerhoff, Thiess Büttner, Finanzwissenschaft (11th edn, De Gruyter Oldenbourg 2015).

${ }^{4}$ The German Council of Economic Experts, Annual Report 2014/15 (Bonifatius 2014).

${ }^{5}$ Dietrich Budäus, Dennis Hilgers, 'Neues doppisches Haushalts- und Rechnungswesen als Grundlage öffentlicher Ressourcensteuerung’ (2010) 5 Betriebswirtschaftliche Forschung und Praxis (BFUP) 62.

${ }^{6}$ Andreas Glöckner, Neue öffentliche Rechnungslegung (Nomos 2014).

${ }^{7}$ Bertelsmannstiftung, KGSt, Manifest zum öffentlichen Haushalts- und Rechnungswesen in Deutschland, (Bertelsmannstiftung KGSt 2009).

${ }^{8}$ Cf. Charles Beat Blankart, Öffentliche Finanzen in der Demokratie (8th edn, Vahlen 2011) 188 et seq.
} 


\section{JURIDICAL APPROACH}

In most European countries, the financial constitutions are based on the idea that the political level defines tasks and the levels of provision. The decision about the necessity of fulfilling the public tasks is in the hands of the parliaments of the respective levels. The implementation of the tasks and the following amount of public spending rests with the administration. The collection of the necessary revenues, e.g. taxes or fees, is regulated in the legislation and therefore decided upon by the parliaments. The tasks lead to spending which must be covered by revenues. The financial constitutions of the states legally rule the distribution of revenues among the different levels responsible for fulfilling the tasks ${ }^{9}$.

A possible approach to a distribution of public tasks on the different levels is the principle of subsidiarity ${ }^{10}$.

Fig. 3 The principle of subsidiarity

\begin{tabular}{|c|l|}
\hline International regimes, e.g. UNO & $\begin{array}{l}\text { Decisions should } \\
\text { be taken as } \\
\text { clousely as } \\
\text { possible to the } \\
\text { citizen. The public } \\
\text { goods are supplied } \\
\text { at the appropriate } \\
\text { level. }\end{array}$ \\
federal state & \\
municipal district & \\
\hline family
\end{tabular}

Source: own depiction. For the principle of subsidiarity cf. Brümmerhoff, Büttner (n 6) 337.

This approach assumes that the smallest administrative unit possible is responsible for fulfilling the task. Only if this unit is not able to do so, is the next higher level responsible. In different countries, there are different structures of the respective levels and the assignment of tasks. The responsibility for education, for example, can be organised centrally or decentrally. For the public good defence, on the other hand, there will be a central responsibility in all European states ${ }^{11}$.

Generally, this means that with regards to the allocation of finances, the level that is responsible for providing the task is allocated the means to do so. The German financial constitution is based on the principle of connectivity. This means that the level responsible for the task is also

${ }^{9}$ Cf. Bodo Leibinger, Reinhard Müller, Herbert Wiesner, Öffentliche Finanzwirtschaft (13th edn, R. v. Decker 2014) 2.

${ }^{10}$ The principle of subsidiarity is regulated in art 5 of the Treaty on European Union. Cf. European Union 'EurLex' $<$ Vertrag über die Europäische Union, Artikel 5 (EUV) und Protokoll (Nr.2), http://eur-lex.europa.eu/legalcontent/DE/TXT/?uri=celex\%3A12012E\%2FTXT $>$ accessed 15 October 2016.

${ }^{11}$ Cf. Horst Zimmermann, Klaus-Dieter Henke, Michael Broer, Finanzwissenschaft (12th edn, Vahlen 2012) 218. 
responsible for the expenses ${ }^{12}$. As a consequence, the responsible level must dispose of the necessary revenues to do so. A possibility to ensure this is to enable the levels to raise the revenues necessary for their expenses independently. Alternatively, the central level can generate public revenues and allocate them to the other levels according to their tasks.

If this approach were applied consistently, there should be no negative financial balances as shown in section 1 . The reality in the last decades shows increased public spending, and, in most cases, financial deficits, even though laws in almost all countries are explicit with regards to public revenues covering public spending. In addition, at the European level there are the Maastricht criteria stating that the public financial deficit must not be more than $3 \%$ of a country's GDP ${ }^{13}$.

\section{ECONOMIC APPROACH}

The rather theoretical economic approach ${ }^{14}$ assumes that the public service or good and its payment are directly related. In this case, the fiscal principle of equivalence takes effect. The duty of payment is only effective in case of claiming the public service. Due to the connection between provision and payment of the service, there is fiscal competition between regions. This concerns the supply of public goods and services as well as the amount of payment due for their utilisation. Therefore, citizens can vote with their feet by choosing the region best suited to their requirements. Public goods and services exist on a national as well as a regional level. Examples are the national provision of the good 'defence' and the regional provision of infrastructure. There is also the possibility of international public goods such as climate protection. The voting by feet is therefore dependent on the sphere of influence of the public good. The theory of federalism assumes that an efficient allocation of the public good is achieved, because the level with the best information about costs and necessary quantities of the good or service provides them ${ }^{15}$.

This concept only works if the necessary information about cost and quantity is available. The development of the financial deficits on a European level shows that either the information is not available or, if it is available, it is not used efficiently. The following section therefore provides a suggestion for the avoidance of financial deficits that applies to countries with juridical as well as economic approaches in their financial constitutions.

\footnotetext{
12 ibid.

13 Cf. Bundesfinanzministerium 'Fiscal Rules', $<$ http://www.bundesfinanzministerium.de/Content/DE/Standardartikel/Themen/Oeffentlich e_Finanzen/Fiskalregeln/nationale-europaeische-fiskalregeln.html\#doc21758bodyText11> accessed 15 October 2016.

14 A complete economic approach cannot be found in any European state. Single components can be found, e.g., in Switzerland.

15 For the theory on federalism cf. Charles Beat Blankart, Öffentliche Finanzen in der Demokratie (8th edn, Vahlen 2011) 613 et seq.
} 


\section{SUGGESTED REFORM}

It can be shown that financial deficits are mainly independent of the regulation of the allocation of finances within a country. Neither a mainly juridical nor a mainly economically based financial constitution leads to balanced finances. This is mainly due to the regulation of spending by considering needs, leading to an automatic deficit in case of high needs. Spending is considered a target figure and revenues must be determined accordingly to cover spending. The system works like a one-way street in only considering one direction.

Fig. 4 The real economic approach

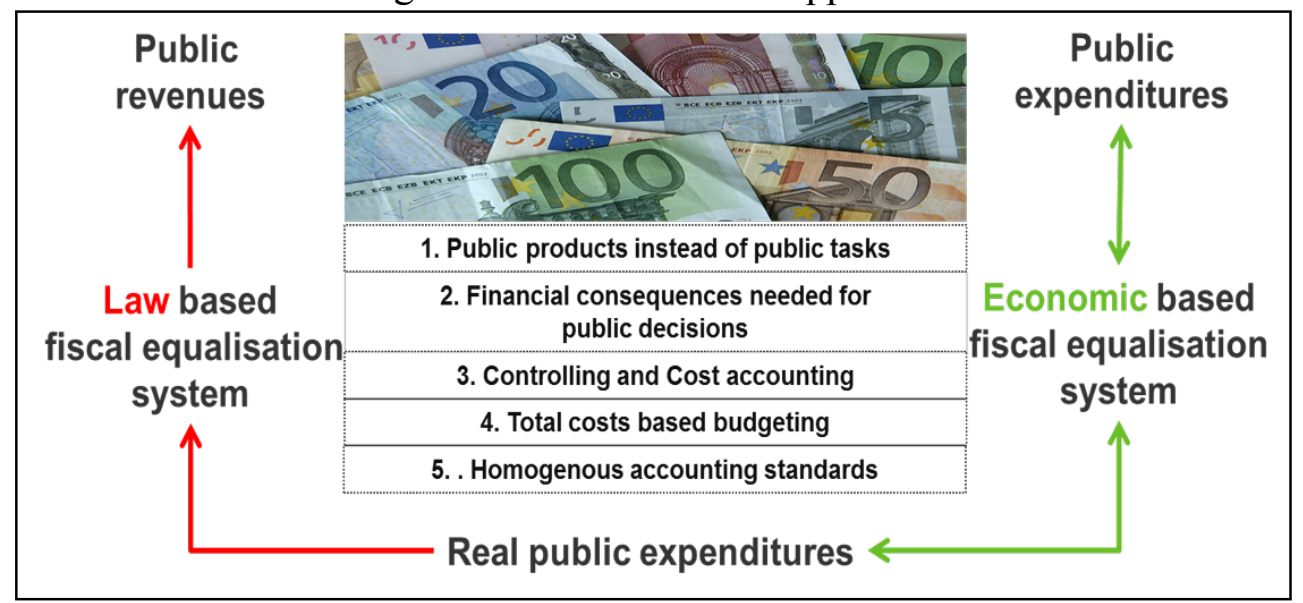

Source: own depiction.

A system solving these discrepancies must therefore also include the spending. Expanding the basic approaches to financial allocation within those parameters, the result is the real economic solution, i.e. a system that leads to an efficient rationing of spending and revenues. Budget controlling is then necessary and further deficits are avoided.

\section{Public Products instead of Public Tasks}

The legal regulations of the allocation of finances are based on the assumption of public task. The formulation and realisation of public tasks focuses on the input side, though. This can be illustrated by the example of a day-care centre. If parents have a legal right for day-care for their children, local authorities must provide a place in a day-care facility. If this is the case, the task is fulfilled. This is the end of the input control. In addition, it is necessary to present the resources necessary to provide the place in the day-care unit. When defining tasks, i.e. the provision of a public service or good, it is not necessary to specify targets such as quality or costs. This is a deficit in the system, because qualified information about the cover ratio or the satisfaction of the users etc. are not possible.

If public services or goods are presented as products instead, one switches from input- to output control. In this case, the resources needed can 
be included and it is possible to state targets and to control whether those targets are reached.

Fig. 5 The product in the new management model

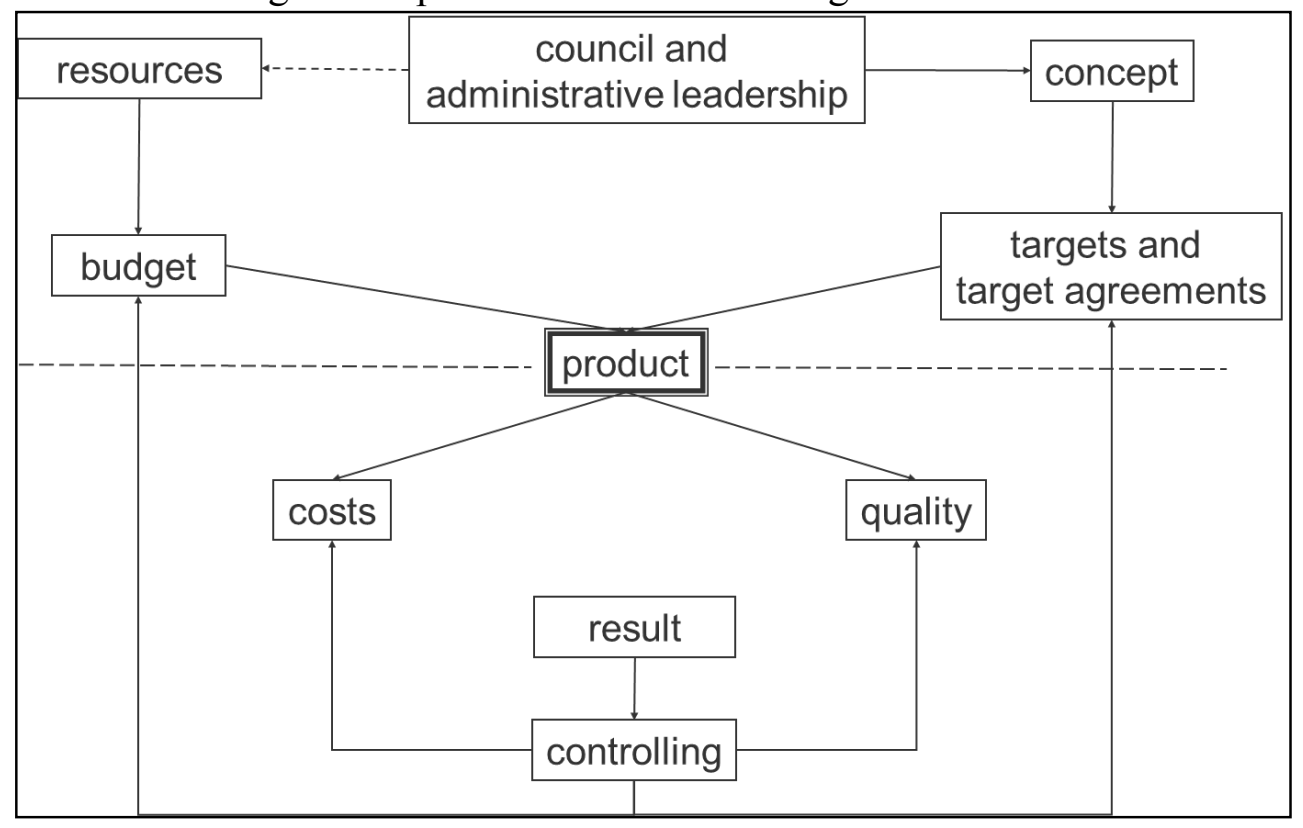

Source: based on Gunnar Schwarting, Effizienz in der Kommunalverwaltung (2nd edn, Erich Schmidt 2005) 38.

As can be seen in the figure above, the product is the focus of the budget management of the new management model ${ }^{16}$. The strategic decision about the provision of a product is made by the council or the administrative leadership. Based on a guiding principle, targets and target agreements are connected with the product and resources and budgets for the provision of the product are planned. The operative level shows the costs and qualities of the product, which then give feedback to the controlling of aims and budgets. In some cases, this will show that budgets are insufficient and must be increased. Based on this management principle, the decision about such an increase can be made based on better information.

\section{Financial Consequences of Public Decisions}

The legal approach to the provision of public goods and services only considers the necessity of fulfilling a task. It defines whether a task is necessary or not, but does not stipulate in which quantity it must be provided. Therefore, the necessity is considered independently of direct and

16 On the new management model cf. Gunnar Schwarting, Effizienz in der Kommunalverwaltung, (2nd edn, Erich Schmidt 2005) 21 et seq. On a community level there is an enhanced version to a community management model, cf. Kommunale Gemeinschaftsstelle für Verwaltungsmanagement KGSt, Das Kommunale Steuerungsmodell (KSM) (KGSt-Bericht 2013, No. 5). 
indirect middle- and long-term costs caused by the product. In Germany, for example, investments in big projects are decided on without reflection on the follow-up costs of the investments. Fulfilling the task is therefore independent of the product costs and the budget.

\section{Controlling And Cost Accounting}

To efficiently fulfil public tasks, they must be defined as products. This enables output management for the completion, i.e. efficient provision, of the task. The target-oriented management of administrative units with the help of controlling systems, which are based on a cost- and performanceaccounting system, is crucial for this approach. With the help of those systems, information about targets such as costs, performance and economic efficiency of the provision are available and can be analysed.

A controlling process that is helpful for the administration ${ }^{17}$ follows the following steps: planning, controlling, information, management. Planning includes the setting of targets and the determination of a budget for the realisation of the targets. Planning therefore anticipates future situations and weighs different alternatives with the help of objective information to set the targets. These decisions are strategic, i.e. the planning horizon is at least five years. It is crucial for the successful implementation of controlling systems in the public sector that there is an awareness for the necessity that the responsible politicians and the managers have to use the planning system and the planning process. The controller only takes over after the planning, i.e. is responsible for the comparison of targets and actual performance and analyses the reasons for possible discrepancies. This is a necessary addition to the planning process to analyse the achieving of the targets. The information system collects information from both the planning and controlling process and uses this as the base for the work of the management unit. In addition, the information system has a reporting function for the analyses made in the controlling system. If all relevant information is available, management can take measures to correct deviations of the actual performance from the planned situation.

The information necessary for the information system comes mainly from the public accounting as well as the public cost- and performance accounting. To ensure the availability of the necessary data, public budgets must be planned according to double-entry bookkeeping standards. Especially the annual accounts according to these standards provide considerable information on the actual performance due to the availability of data in the balance of accounts, profitability analysis and financial accounting $^{18}$.

In addition, budgets based on double-entry bookkeeping are a part of the planning system, because they show monetary consequences of future events for every product. This information is supplemented by an

\footnotetext{
${ }^{17}$ On the controlling process for the administration cf. André Tauberger, Controlling für die öffentliche Verwaltung (Oldenbourg 2008) 31 et seq.

18 Cf. Isabelle Jaenchen, 'Das Sächsische Kommunale Kennzahlensystem. Eine Empfehlung für die sächsischen Städte, Gemeinden und Landkreise (2012) 4(12) Sachsenlandkurier 162.
} 
assignation of costs by cost type to their cost unit or cost centre and the resulting information on actual costs of the provision of different public goods or services.

\section{Total Costs Based Budgeting}

Budget regulations and budget institutions in the public administration are necessary to improve budgetary discipline. ${ }^{19}$ The target of budgeting is to improve aggregated financial discipline, to attain allocation efficiency (allocation of resources according to the formulation of the political will and objectives) and the technical efficiency (efficient provision of public goods). The improvement of the aggregated financial discipline can be among the macroeconomic targets of a state. Achieving allocative efficiency is a target of the relevant level, and technical efficiency is an operative target for the level realising the provision. ${ }^{20}$ policy $^{21}$. They are as follows:

In 1998, the World Bank published basic rules for a solid budgeting

- Comprehensiveness and discipline.

- Legitimacy.

- Flexibility.

- Predictability.

- Contestability.

- Honesty.

- Information.

- Transparency and accountability.

Especially for the principle of information, but based on the information also the principles of honesty and transparency, it is necessary to include all costs resulting from the provision of public goods and services. Budgeting based on the inclusion of total costs is therefore essential. To achieve this, it is necessary to change the management system to one based on products, and to transfer the budget and accounting system to double-bookkeeping principles ${ }^{22}$.

The product-oriented booking of expenditures and revenues leads to necessary insights for the creation of cost- and performance-accounting systems. If cost- and performance-accounting systems are introduced, necessary information about costs, but also output and outcome, are available. This information is essential for a planned and systematic budgeting.

\footnotetext{
${ }^{19}$ Cf. Angelika Pasterniak, Budgetregeln und die Qualität der öffentlichen Finanzen (1st edn, Deutscher Universitätsverlag 2006) 8.

20 ibid 67 et seq.

21 The World Bank, Public Expenditure Management Handbook (The World Bank Washington D.C. 1998).

22 Rainer Isemann, Christian Müller-Elmau, Stefan Müller, Kommunales Gemeinkostenmanagement (Erich Schmidt 2011) 17 et seq.
} 


\section{Homogeneous ACCOUNTING STANDARDS}

Allocative and technical efficiency can only be realized if the necessary information about the disposable resources and their optimal allocation is available. The predominant system in Europe, the cameralistic accounting, does not provide this information. It only contains information suitable for input-control, but not the necessary data on costs, output and outcome. Therefore, the European Commission strongly promotes the introduction of consistent budget- and accounting standards (EPSAS) ${ }^{23}$. The transfer from cameralistic to double-entry accounting and the subsequent target-oriented use of the information about costs, output and outcome is essential to produce balanced budgets. The objective of a harmonised solution for all member-states is the provision of comparable budget- and annual account-data for all member-states. Only then is a target-oriented management with the help of the aforementioned instruments possible. The political resistance to the introduction of harmonised European standards, especially in Germany, is large, though. In Germany there are 16 different regulations of the federal states for the districts. The restructuring of the budgets of the Länder follows different standards.

Fig. 6 State of the realisation of harmonised standards

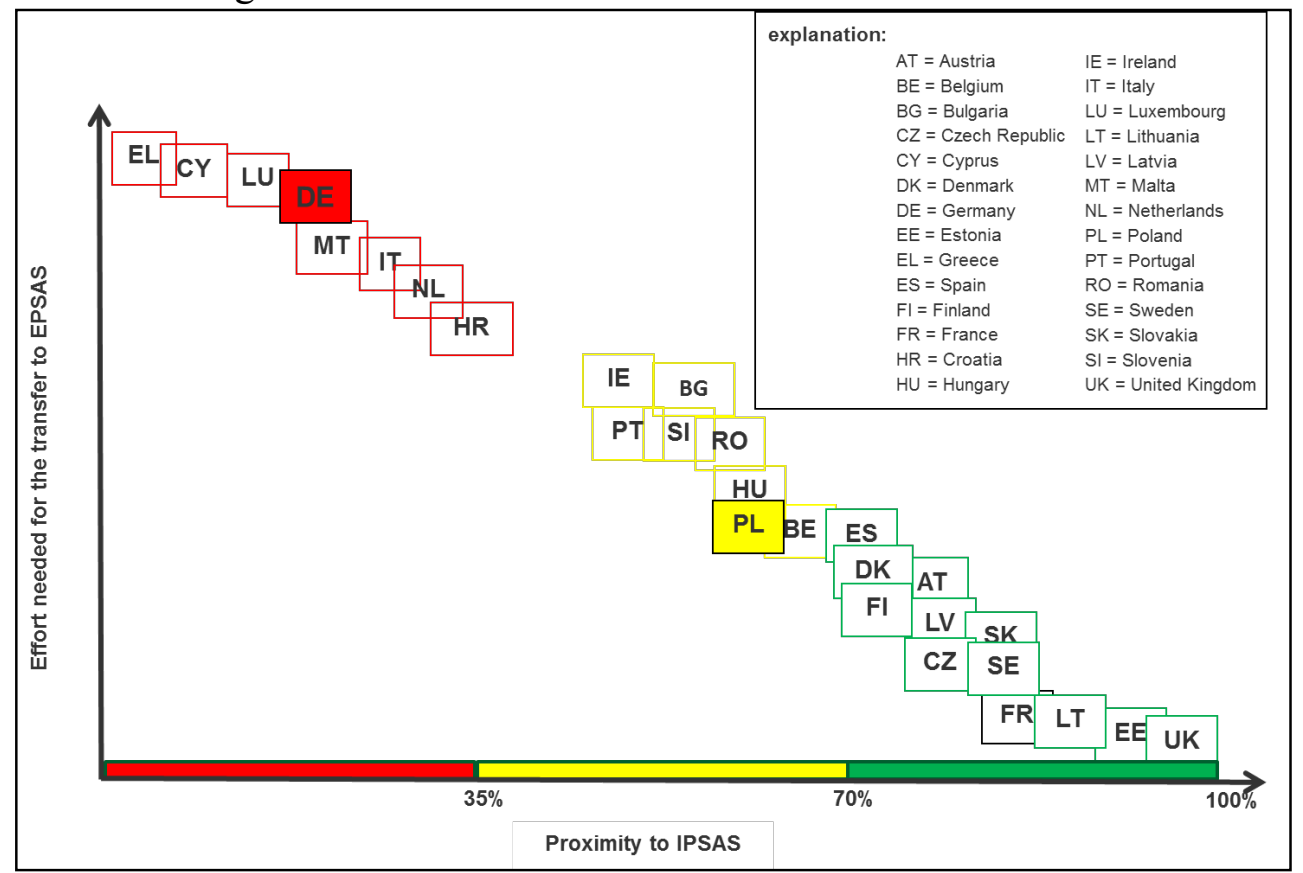

Source: own depiction based on data from Dennis Hilgers 'Die Dispersion der Doppik' <http://www.haushaltssteuerung.de/weblog-die-dispersion-derdoppik-das-neue-oeffentliche-haushalts-und-rechnungswesen-zwischenkommunaler-routine-und-europaeischer-harmonisierung.html.> accessed 15 October 2016.

\footnotetext{
${ }^{23}$ EPSAS: European Public Sector Accounting Standards based on IPSAS, International Public Sector Accounting Standards, cf. EPSAS 'Towards harmonized European Public Sector Accounting Standards' <www.epsas.eu> accessed 15 October 2016.
} 
In addition, the need for reforms as well as the effort needed for the transfer to EPSAS on the German federal level is very high and the proximity to the IPSAS standards very low (less than $35 \%$ ) compared to other EU member states. Poland has to put considerably lower effort into the transformation and has a much higher proximity to the IPSAS (66\%), even though it is not one of the most advanced states in this respect. Almost half the EU member states have a degree of proximity of more than $70 \%$ to the IPSAS and therefore a considerably lower effort to transform and lower need for reforms.

\section{CONCLUSION}

Bringing about the suggested reform is independent of the state structure. Parts of the reform have already been completed in some EU member states, and the development of harmonised budget- and accounting standards on a European level shows a solution to the dilemma. An integrated system with revenues and expenditures leads to considerably higher transparency ${ }^{24}$. Currently, the individual states are working on partial solutions, though, therefore, the introduction of double-entry bookkeeping standards as well as harmonised accounting systems in all EU member states are still lacking.

In addition, a clear assignment of tasks and the accompanying assignment of responsibilities is crucial for a successful realisation of the reform. It is also necessary to transfer public tasks to public products which must then be classified as either tradable goods, e.g., childcare, and sovereign, e.g. defence and security. Tradable goods could be managed as service with return service according to the principle of fiscal equivalence; sovereign goods can be managed as basic requirements.

If the assignment of tasks is clear and costs are transparent due to the parameters introduced above, the revenue competences of the responsible levels must be regulated. This increases institutional congruence and creates better regional identities for the use of public goods.

The relevant instruments to effect the reform are well-known. Therefore, the current task is to increase the willingness to implement the existing instruments.

This paper offers the groundwork for the combination of public income and public spending. Further research should aim at the development of integration approaches for a more efficient public administration.

\section{References}

Blankart Charles B, Öffentliche Finanzen in der Demokratie (8th edn, Vahlen 2011)

\footnotetext{
${ }^{24}$ Cf. Isabelle Jaenchen, 'Kommunaler Investitionsbedarf und Liquidität - eine doppische Betrachtung' (Winter 2015) Public Governance 16.
} 
Brümmerhoff Dieter, Büttner Thiess, Finanzwissenschaft (11th edn, De Gruyter Oldenbourg 2015)

Budäus Dietrich, Hilgers Dennis, 'Neues doppisches Haushalts- und Rechnungswesen als Grundlage öffentlicher Ressourcensteuerung' (2010) 5 Betriebswirtschaftliche Forschung und Praxis BFUP

Glöckner Andreas, Neue öffentliche Rechnungslegung (Nomos 2014)
Hilgers
A 'Die
Dispersion
der
Doppik'

$<$ http://www.haushaltssteuerung.de/weblog-die-dispersion-der-doppik-dasneue-oeffentliche-haushalts-und-rechnungswesen-zwischen-kommunalerroutine-und-europaeischer-harmonisierung.html.> accessed 15 October 2016

Isemann Rainer, Müller-Elmau Christian, Müller Stefan, Kommunales Gemeinkostenmanagement (Erich Schmidt 2011)

Jaenchen Isabelle, 'Das Sächsische Kommunale Kennzahlensystem. Eine Empfehlung für die sächsischen Städte, Gemeinden und Landkreise‘ (2012) 4(12) Sachsenlandkurier

Jaenchen Isabelle, 'Kommunaler Investitionsbedarf und Liquidität - eine doppische Betrachtung' (2015) Public Governance

Leibinger Bodo, Müller Reinhard, Wiesner Herbert (2014): Öffentliche Finanzwirtschaft (13th edn, R. v. Decker)

Pasterniak Angelika, Budgetregeln und die Qualität der öffentlichen Finanzen (1st edn, Deutscher Universitätsverlag 2006)

Schwarting Gunnar, Effizienz in der Kommunalverwaltung (2nd edn, Erich Schmidt 2005)

Tauberger Andre, Controlling für die öffentliche Verwaltung (Oldenbourg 2008)

Zimmermann Horst, Henke Klaus-Dirk, Broer Michael, Finanzwissenschaft (12th edn, Vahlen 2012) 